\title{
The Brand Creation Process in the Information Technology Sector: The Case of Brasil IT+
}

\author{
Naya Jayme Ringer \\ University of São Paulo, Brazil \\ E-mail: naya.jayme@gmail.com \\ Janaina de Moura Engracia Giraldi \\ University of Sao Paulo, Brazil \\ E-mail: jgiraldi@usp.br \\ Angélica Ferreira Capellaro \\ University of São Paulo, Brazil \\ E-mail: angelcap@gmail.com \\ Lara Bartocci Liboni Amui \\ University of São Paulo, Brazil \\ E-mail: lara.liboni@gmail.com
}

Received: November 19, 2012

Accepted: January 17, 2013

Online Published: March 14, 2013

doi:10.5430/ijba.v4n2p27

URL: http://dx.doi.org/10.5430/ijba.v4n2p27

\begin{abstract}
Sector brands are an alternative to the impossibility or inadequacy of developing national country brands. However, studies examining the subject are scarce. This article examines the development process of the Brazilian information technology sector brand and contributes to the understanding of sector brands. The empirical study is a case study of the Brasil IT+ brand, which was created to strengthen Brazilian information technology sector exports. The study concludes that the process of creating the Brasil IT+ sector brand was suitable according to the literature on brands, although certain aspects of the process could have been improved. For example, the brand could be adapted to each type of target audience and should control exports and the quality of the enterprises that conduct business under the brand. It was also possible to determine that the brand is investing in the construction of a competitive differentiator for the Brazilian sector, which will generate increasingly more competitive advantages for the enterprises that use the sector brand as a form of marketing in the international market.
\end{abstract}

Keywords: IT sector, Sector brands, Brazil

\section{Introduction}

In an increasingly complex and inter-connected world, not only enterprises but also countries compete on every level (Fetscherin, 2010). Many countries already view national reputation as a key issue and its management as an important strategic consideration (Kotler \& Gertner, 2004). Because of this strategic importance, brand construction and brand management is now also used by governments to promote their cities, sectors and countries among other uses.

The management of country brands is analogous to the management of product brands. However, this new type of brand represents intangible products and promotes matters, such as climate, environmental conditions and culture, among other national characteristics (Bivolaru, Andrei \& Purcăroiu, 2009).

Although similarities exist between the creation and management of product brands and "place brands", the development of "place brands" is much more complex because of such difficulties as the need to create integrated 
communication regarding national characteristics or to modify characteristics to represent them in the brands. This task is significantly more straightforward with products. Dinnie (2008) adds that aside from their complexity the management of country brands is challenging because little theory exists on the subject, although significant practical activity occurs in the field.

Another factor that must be considered when discussing country brands is the "country of origin effect", which refers to the effect that the country of origin has on consumer behavior in relation to imported products. If a consumer believes that Häagen-Dazs is a Danish ice-cream, he or she will associate significantly different ideas with the brand than another consumer who knows that the brand is American (Magnusson, Westjohn \& Zdravkovic, 2011).

According to a study by Domeisen (2003), the following points should be considered with respect to the management of country image and to understanding the effect that the country of origin can have on the management of the country's brand. Countries must be sure that they understand how they are perceived abroad. They must invest in independent research focused on the perception of their products and country characteristics. Finally, the characteristics selected for promotion should have a basis in the business reality.

Representing the various sectors of a given country with a country brand is difficult. Confronted with such a challenge, it can be convenient for a country to create sector brands, which, according to Domeisen (2003), can be used successfully by countries that have not established a national brand. In addition, sector brands can be convenient for countries that do not consider the construction of a national brand as viable or that do not believe that generalizing various sectors under the same brand is appropriate.

Certain products and services may not be directly linked to the image that is held of a given country. In this case, it is interesting that an "umbrella brand" can be created for the enterprises of a given sector, always with the goal of collaboration among the enterprises to acquire foreign markets.

In this context, the brand Brasil IT+ was launched to represent the Brazilian information technology (IT) sector, which is a growing sector in the country. Brasil IT+ is an effort to promote the technology industry and boost exports. A primary objective of the brand is to emphasize the sector's competitiveness while clearly differentiating Brazil from India, which is one of this international sector's principal participants (Pavoni Junior, 2010).

Brasil IT+ is a sector brand, and it has been used to promote the sector to the detriment of the national brand. Considering that studies of sector brands are scarce in the literature, the main objective of this article is to understand the development process of this type of brand, specifically the case of the Brasil IT + brand, with the goal of advancing the understanding of the subject. Specific objectives include comparing the development process of the Brasil IT + brand with processes described in the brand literature and outlining possible sources of competitive advantage for the IT sector based on the history of the Brasil IT+ brand. The case study method was used in combination with data triangulation. A review of the literature on country and sector brands is presented next.

\section{Country Branding}

Iversen and Hem (2008) demonstrate that establishing a connection with the image of a place can cause secondary associations. When a brand becomes connected to a location, perceptions of the location (both cognitive and emotional) become indirectly associated with the brand, creating inferences regarding it.

Dinnie (2008) defines country brand as the unique, multidimensional mixture of elements that supply the nation with cultural differentiation relevant for all of its target audiences. This definition agrees with Kotler and Gertner's (2004) comment that countries are increasingly attempting to overcome their competitors, always with the goal of selling more products and services and attracting investment, businesses and tourists. In this sense, Jaffe and Nebenzahl (2001) affirm that the development of a core message about the country, which can be used by different industrial sectors, is important to the success of a country brand. In addition to restoring damaged international credibility, the core message can increase international political influence and stimulate strong international partnerships (Yan, 2008).

Kotler and Gertner (2004) affirm that in many countries, authorities admit that the national reputation represents an important asset that must be managed. However, even when a country does not consciously manage its name as a brand, individuals continue to hold images in relation to the country that are evoked simply by pronouncing the country's name. This phenomenon can influence purchasing, investment and relocation and travel decisions (Kotler \& Gertner, 2002).

Domeisen (2003) agrees, arguing that national branding consists of developing an image and communicating it internally and externally based on positive values and the perceptions of the country that are relevant for the 
development of exports. During this process, the brand concepts are researched, tested and defined. Afterwards, they provide the basis of targeted campaigns to promote commerce, tourism and investment.

The impact of a country image on the management of a country brand is an important consideration. Anholt (2000) argues that origin is a powerful element with respect to brand equity, and there are enterprises that disguise the true origin of their products when disguising can benefit a product or service.

According to Kotler and Gertner (2004), consumers choose products using country of origin as an indicator of quality, whereas Han (1990) clarifies that consumers use country of origin as a means to infer product attributes when the attributes are not known. Similarly, Roth, Diamantopoulos and Montesinos (2008) argue that a product's nation of origin can be considered a driver of a consumer's product evaluation. For Giraldi and Carvalho (2009), the country of origin effect significantly influences behavior and attitudes related to products or brands that originate from a given country.

Regarding nationalities, Kotler and Gertner (2004) discuss another possible effect: a feeling of animosity that can develop in a national population. This feeling arises when individuals consider their own country to be an ideal model and thus reject what originates elsewhere. Such rejection can be labeled ethnocentrism, defined by Shimp and Sharma (1987) as a tendency for individuals to consider products manufactured in their own country as superior to those from other countries. For these same researchers, in these cases, consumers consider it unpatriotic or immoral to purchase foreign products because they believe that purchasing such products creates unemployment and additional negative consequences for their country's economy.

Therefore, the home country of a brand behaves exactly like the parent company of a given product. In the best case, the country of origin can act as an umbrella of quality that assures consumers that they are buying from a trustworthy source. In the worst case, an inappropriate or negative image can make it difficult to export products whose origin is not disguised (Anholt, 2000). Roth, Diamantopoulos and Montesinos (2008) affirm that country of origin can be part of the brand equity of certain brands of a given country and that the origin of a given brand can create intangible assets or liabilities in the minds of consumers. These assets or liabilities will be shared with other brands of the same nationality. The management of these aspects and values related to the brand of a given country originates in their creation, as explained below.

\section{Development Phases of Country Brands}

One of the factors that must be considered with respect to the creation of a country brand is the identification of a country's strengths and weaknesses. These strengths and weaknesses can include anything from the size of the internal market to the population's level of education. Additionally, it is important to understand the opportunities, threats and competitive forces in the international environment (Kotler \& Gertner, 2004).

Kotler and Gertner (2004) suggest a five-stage model for the creation of a national brand. The first stage involves analyzing and defining the main strengths and weaknesses as well as the opportunities and threats. Next, key sectors, personalities, natural landmarks and events should be selected to form a solid brand strategy and an interesting narrative. The third stage includes the development of an "umbrella" concept that includes and is coherent in relation to all of the activities related to the brand. Next, sufficient national funds should be provided to each activity related to the development of the brand to guarantee that the brand's impact will be significant. Finally, export controls should be established to ensure that all of the exported products are trustworthy and achieve the promised level of quality.

Kotler and Gertner's (2004) model proposes that a strategic analysis be performed of the characteristics of the locality before the principal aspects that will be focused on are selected. Additionally, government should become involved through the establishment of national funds and the creation of export quality control mechanisms to guarantee that the brand evokes positive associations. However, according to Domeisen (2003), the experience of countries that have had success in the creation of a country brand suggests that there is a "best practice" to follow to obtain positive results. This best practice is presented in Table 1.

Similarities and differences exist between Domeisen's (2003) model and Kotler and Gertner's (2004) model. Domeisen (2003) also proposes that the process begin with a survey of the country aspects that will be used in addition to suggesting that a group be created that includes the government to manage brand creation. However, the author argues that the government later be excluded from the process to ensure the continuity of the adopted strategies by preventing damage to the development and administration of the brand by changes in government.

Brymer (2005) also supports the idea that the development of country brands must receive the support of representatives from government, business, art, education and the media. The author includes in his model the 
necessity of discovering how a country is perceived internally and by those individuals in other countries whom the goal is to influence. Thus, quantitative and qualitative methods should be used. According to Brymer, the key to the successful development of a country brand is an integrated vision and consistently first-rate quality (Brymer, 2005).

However, the development of country brands is more appropriate for such sectors as tourism and ecotourism because these sectors possess a natural connection with the country brand. Although this type of brand can also be used successfully by other sectors, the development of sector brands is an option for countries that do not consider a country brand suitable or viable, for example, because of a certain difficulty in developing a country brand or enabling it to represent highly diverse sectors. One such example, which is a case with positive results, is that of Café de Colombia (Domeisen, 2003). The literature does not offer many examples that describe the development of sector brands. Therefore, only a small number of discussions related to the subject will be presented in the following section.

\section{Sector Brands}

According to Keller (1993), a country's branding strategy is the most important factor affecting the strength of associations with national products and brands and the country brand. Iversen and Hem (2008) believe that a country can associate its image with brands in three ways. The first way is when a country develops products with individual brands and does not explicitly mention the country of origin. The example provided is that of Sweden, which is home to brands such as IKEA, Volvo and Ericsson, the nationalities of which are well-established in the consumer mind. The second way is when a country chooses a hybrid strategy of sub-branding, combining the names of individual brands with their place of origin. One example is the brand "ZESPRI - New Zealand kiwi", which uses the slogan "Our Kiwi has a unique difference. It is named after New Zealand". Finally, a country can develop a name shared by all of the country's products and services within a given sector or category, for example, Café de Colombia, the export brand of all Colombian coffee.

The second and third strategies can be classified as umbrella brands (Iversen \& Hem, 2008). The last strategy is known as a sector brand. Sector brands are alternatives to a national brand for countries that do not believe that a national brand is appropriate (Domeisen, 2003).

In the case of Brazil, the national brand (Brazil Brand) was developed through an initiative of the Ministry of Tourism (Brasil, 2010) and is composed of such elements as the samba, happiness, the beach and sunshine. These images can represent many sectors well, from tourism to fashion, although the brand does not fit certain sectors well, such as the technology sector (Rocha \& Mello, 2011).

Many different sector brands exist besides the national Brazil brand and they are developed and managed mainly by Apex-Brasil (the Brazilian Trade and Investment Promotion Agency). The agency endeavors to introduce Brazilian enterprises into the international market, diversify and add value to Brazilian exports and increase export volume. This agency aims to strengthen the Brazil's participation in the country's traditional markets and acquire new markets for Brazilian products and services (Apex Brasil, 2009).

The concept of brand architecture can be defined as an integrated process of brand building through the establishment of brand relationships among the brand options in the competitive environment. Brand architecture can help in the revitalization or fusion of brands that have low impact in the market and tend to cause organizational conflicts with strong enterprise brands (Rajagopal \& Sanchez, 2004). In this way, sector branding can collaborate in the establishment of a relationship between the administered sector brand and the enterprises involved in the process according to Apex Brasil (2009). Additionally, a sector brand can emerge as part of a strategic alliance among enterprises in the same sector, an alliance that can offer economies of scale, for example. This phenomenon occurred in the case of airlines, which united to form the global brand "oneworld" (He \& Balmer, 2006).

The literature on sector brands includes examples of national brands that were only used for certain products of their origin nations, such as Australian wine, (Alonso \& Nothcote, 2009), Canadian meat (Blue, 2009) and Colombian coffee (Federacafe, 2010).

In Brazil, many sector brands are supported by Apex Brasil in the development of a unique element of communication that symbolizes the activities of these sectors. The creation of Brasil IT + resulted from the Integrated Sector Projects, which were developed by the Technology Complex. These projects had the goal of "increasing exports of software products and services by means of approaching the external market by business segment and vertical expertise" according to Apex Brasil (2009). Brasil IT+ is one of the brands whose development was supported by Apex Brasil as an Integrated Sector Project and in partnership with other entities. 
The IT sector has received special attention given its growth potential, which is exemplified by Apex-Brasil's efforts to promote the sector's development and exports.

\section{Methods}

A qualitative study was conducted to achieve this article's objective. We intended to increase the understanding of the process of creating and developing sector brands based on an analysis of Brasil IT + . Considering that this study intended to answer the "how" of brand development in addition to generally examining the contemporary phenomenon of the creation of sector brands and Brasil IT + in particular, the application of the case study method was considered appropriate.

The Brazilian IT sector was selected for study because Brazil has become more competitive in the IT market and it has risen from 10th to 5th position in the offshore destination ranking according to Apex Brasil (2011). The Federal Government's Industrial Development Policy (PDP), launched in May 2008, considers the Brazilian software and IT services sector to be strategic. In 2008, Brazil had 48\% of the Latin American market, the value of which is estimated at US\$61 billion (Apex Brasil, 2011). The agency observes that in this sector, Brazil possesses the conditions to compete with India, which is notable for its pioneering IT innovation. This observation is particularly valid with respect to the strong reputation of Brazilian IT enterprises in the banking and telecommunications sectors. Forecasts of new opportunities for Brazil in Internet banking are increasing, representing a niche market in which India does not possess the same international reputation.

In addition, the sector illustrates how sector brands must be built when the relationship between the products offered and a country's international image is not strong. For example, Brazil possesses a strong international image linked to its natural resources but with little connection to technological development and innovation. Therefore, such sectors as the IT sector are forced to create a sector brand that can promote the sector and its country of origin by modifying the established image and constructing a new international image.

In this regard, the adequate development of this sector's brand is a key strategy to differentiate Brazilian services from those of other countries. To aid in data collection and analysis, questions and propositions were elaborated from the case study following Yin's model (2009). In this way, questions and propositions came to the forefront based on the study's objectives and the literature reviewed. These questions and propositions are presented in Table 2 .

In the present study, the unit of analysis is the process of the creation of the Brasil IT+ brand and ranges from the perception of the necessity of brand creation to the brand's effective use by sector enterprises. An in-depth interview with an Apex-Brasil member was conducted to achieve the study's objectives. In addition, information from secondary data sources on the Brasil IT+ brand was analyzed, including journals, magazines and Internet sources. Particularly important were the Brasil IT + Guide and material made available by Apex-Brasil that had been elaborated during the consultancy responsible for the development of the brand. The guide was designed for brand publicity and presented guidelines for the use of the logo, colors, graphics, typography and photographic style, as well as examples of how to apply the logo and which versions to use.

To analyze the primary and secondary data, a content analysis technique was used that combined the different data sources. This approach improved the accuracy of the final conclusions (Jack \& Raturi, 2006).

\section{Results and Discussion}

In this section, the brand creation process of Brasil IT + is presented followed by an analysis of the study's questions. The Brasil IT+ brand is part of a project aimed at incentivizing exports in the Brazilian IT sector. Additionally, it is part of the Technology Complex's Integrated Sectoral Projects program, through which Apex-Brasil and other institutions related to the sector promote actions to strengthen the sector in international markets. Previous to the brand development, a study was performed by sectorial associations to identify the sector's internal and external perceptions and images. The study determined the opportunities and threats in the international market that influenced the direction of the internationalization process followed by Brazilian IT sector enterprises. The brand development involved 12 entities in addition to Apex-Brasil. These entities included ABDI (the Brazilian Agency for Industrial Development), ABES Software (the Brazilian Association of Software Companies), ANPROTEC (the National Association of Promoters of Innovative Enterprises) ASSESPRO (the Association of Brazilian Information Technology Companies), BNDES (the Brazilian Development Bank), BRASSCOM (the Brazilian Association of Information and Communications Technology Companies), FENAINFO (the National Federation of Information Technology), the Ministry of Science and Technology, the Ministry of External Relations, the Ministry of Development, Industry and Foreign Trade, SOFTEX (the Association for the Promotion of Brazilian Software Excellence) and SUCESU-NACIONAL (the Association of Information and Communications Technology Users). 
The technology sector associations made investments to develop the brand with which Apex-Brasil established agreements to create the Brand Management Committee. These entities established a consensus regarding brand use, attributes and positioning, mainly in international events, such as fairs. The goal was to publicize the brand in a manner that would ensure its continuity and guarantee its independent management, thereby decreasing its vulnerability to changes in government and institutional leadership.

According to Apex-Brasil, the interest in the development of a brand that unifies and represents the Brazilian IT sector appeared in 2004 with the creation of the "Brazil IT brand". This brand was exclusively focused on the American market. In 2009, the entities involved with the brand promoted its revitalization. The revitalization resulted in the launch of "Brasil IT+", which includes among its objectives a global reach (although the country name was then written in Portuguese). According to Apex-Brasil, the necessity of sector representation resulted from the desire of the institutions and companies involved, which believed in the capacity of Brazilian IT to foster national and international business. These institutions and companies perceived the brand as a means to contribute to the development of the country and the consolidation of the Brazilian IT sector as an option in the world market.

According to the Apex-Brasil member interviewed, the brand was intended to certify the Brazilian sector's competitiveness and quality in relation to its international rivals. In addition, the brand was to guarantee the delivery of practical, efficient and innovative solutions and emphasize attributes that only Brazil can offer, such as "business expertise, creativity, flexibility, diversity, infra-structure and excellent conditions to make solid partnerships."

The aim was to create a source of competitive advantage by focusing on these characteristics and generating more visibility for the sector, thereby strengthening the sector and increasing the awareness of it. Additional goals included transmitting credibility, capacity, knowledge, security and quality.

The creation of the brand intended to reduce noise in relation to Brazil by building a positive and serious image of the country, specifically of its IT sector, and to create continuously available qualified labor. Brazilian IT primarily markets services. Marketing services demand an image related to a Brazil that is well-known for IT. Therefore, the challenge is to move beyond the perception of Brazil as a country that only supplies natural resources. To reach the objectives proposed for the brand, it was determined that the images and meanings to be transmitted by the brand should be represented by four pillars. Using these pillars, the unique and differentiated image of a Technological Brazil could be formed. According to the Brasil IT+ Guide, the pillars are as follows:

1) Being Brazilian: The brand aims to communicate that being Brazilian is the result of mixing ethnicities and that the capacity to live together and have friendly relations with individuals of different cultures and origins is a result of this mixing. Therefore, there is a better understanding of the needs of diverse customers. Additionally, the pillar aims to link the well-known flexibility and optimism of Brazilians with the ability to overcome crises and generate creative and innovative solutions and thus pursue responsible growth by offering increasingly better products and services.

2) Transportation capabilities: This second pillar aims to emphasize that Brazil is a country of continental proportions with a large quantity of natural resources and a considerable economic-industrial complex. A country with such attributes demands large-scale infrastructure and transportation and telecommunications networks to connect cities and individuals. The idea is to emphasize the country's increasingly highly developed technology and, with its growing number of IT specialists, how Brazil is preparing to overcome its limitations.

3) Building high-quality partnerships: The objective is to show the market that a country that already possesses expertise in conducting business with buyers and suppliers from diverse segments of the economy has a guaranteed capacity to transfer this ability to the IT sector. This pillar emphasizes Brazil's proximity to important markets, political-economic stability, cultural diversity and its democratic legal system as the country's attractive characteristics.

4) Being a strategic player in IT: The objective is to show that investments in the sector helped the sector attain a capacity to overcome challenges to such an extent that it became recognized nationally and internationally. According to Apex-Brasil (2009), the country is recognized today for developing innovative and consistent solutions and for being an intense user of global standard platforms, architectures and methods.

The photography that accompanies the promotional materials aims to present these attributes and images with clarity, amplitude and openness (in accord with the applications, occasions, the target audience and the breadth of communication) to link the selected values to the brand elements and represent, qualify and certify the Brazilian IT sector. According to Apex-Brasil, the objective is to convey a "technological Brazil and dynamic scenarios. Solid and connected, which builds and adds without losing originality and creativity. Bright in its landscapes, diverse and 
human in its people. A country captured in its own tones with a naturalness that makes it rich and with an emotion that makes it unique". An attempt was made to combine Brazilianness with attractive business differentiations in diverse markets and associate the principal characteristics of the sector with the country and thus illustrate the competitiveness of the Brazilian sector.

Regarding the choice of the brand name, the goal was to find a unique name that could describe the sector neutrally while showing the sector's unity in relation to the strategy and the different coexisting initiatives. Additionally, a name was sought with an origin and a purpose that were clear. Moreover, the interviewee noted that there was a concern during the name's creation that the name be applicable in a global environment. One outcome of this concern was the determination to spell "Brazil" with an "s", in other words, to adopt the official language of Brazil and convey authenticity. To increase the brand's memorability, the logo is accompanied by the slogan "Value beyond expectations". This slogan aims to translate the values that the brand embodies and emphasize that Brazil possesses a stronger and more developed IT sector than the world market appreciates.

Importantly, the brand underwent certain adaptations after its creation in 2004. In addition, rules were created for the use of the brand, which enterprises should respect. These rules were created to preserve brand integrity and readability across the diverse situations of the brand's use. Another brand-protective tool was the brand's legal protection by registration. According to the interview with the Apex-Brasil member, there currently are no criteria for the selection of enterprises that want to join Apex-Brasil to use the brand-sector publicity. However, there are criteria with respect to the suitability of business enterprises for each project. To use the brand, enterprises should correctly follow the guidelines outlined in the brand's usage manual, which indicate, for example, the color variations that may be used with the logo among other graphic details. In this way, the brand represents all of the involved entities' individual brands in the construction of the project as a whole with the goal of creating a seal of approval for the enterprises linked to Brasil IT+. Although administered with the government, there are programs based on private initiative to ensure the quality of the products and services included by the brand. The programs exist in the sense of increasing the maturity and quality of the solutions and services provided, although there is no direct control by the Brand Management Committee.

The Brand Management Committee is aware that the brand should be developed and consolidated gradually. The first step was to attract the attention of the market to Brazil's substantial capacity to supply IT solutions. The next step should be to emphasize the Brazilian characteristics that differentiate the Brazilian IT sector from its competitors around the world. Consequently, the discourse should be focused and emphasize Brazil's potential. In addition, it should be mindful of the assertiveness of the promotional actions and use of the brand by Brazilian enterprises in their own individual discourse throughout their internationalization processes.

According to Apex-Brasil, the brand will undergo a further revision to connect its use more closely to its proposed objectives. The Brand Management Committee believes that the brand is already reasonably recognized by customers and competitors. Therefore, the next step consists in maturing and strengthening the image globally.

\subsection{Analysis of the Process of Creating the Brasil IT+ Brand}

In relation to the first specific objective ("comparing the Brasil IT+ brand's development process with such processes described in the literature on brands") and its respective question ("Did the process of brand creation follow established standards outlined in the literature?"), an analysis of certain relevant points is necessary. An initial response to this question is that the brand creation did follow an established method. It was possible to observe diverse steps and aspects of brand construction in the case study, which is why one can partially conclude that the brand's development proceeded according to the literature. This conclusion is supported by the descriptions below.

For example, regarding the consolidation term, the literature indicates that the managers should be conscious that the development and consolidation of a brand is a long-term process (Domeisen, 2003). The managers of Brasil IT+ possess that understanding and know that they should always be conscious of the market's awareness of the brand and the market's maturity to plan adequate actions to achieve the proposed objectives. In addition, the creation of the Brand Management Committee renders brand management effectively independent of any institution, making the brand less vulnerable to changes in government and leadership. This observation confirms that a structure parallel to the government exists that is responsible for brand management.

The formation of a Management Committee can be considered relevant to the process of sector brand creation and management because such a committee makes financing for the process possible and provides a variety of perspectives, which can enrich the strategies adopted for the brand and enable a more accurate analysis of the target 
market and competitors among other factors, which is fundamental to the determination of an action plan that contributes to the brand reaching its objectives.

Another point that accords with Kotler and Gertner (2004) is that brand creation requires adequate financial support from the organizations involved. The process relied on a budget that originated from agreements between Apex-Brasil and other institutions, which later became integrated into the Management Committee. Regarding the definition of values to be represented by the brand, the process of creating Brasil IT+ follows the recommendation of Domeisen (2003). The sector and country values were defined previously and linked with the business reality, thus associating the brand with the IT sector.

Regarding previous studies, Murphy (1987) notes that it is interesting to analyze strengths and weaknesses, as well as opportunities and threats, for Brazil in potential markets and to seek to understand how the country is perceived abroad. According to the interviewee, this analysis occurred based on Apex-Brasil's experience in these markets over the past 13 years, a period during which information was gathered that was useful for the brand development. Murphy also notes the need to take action based on the information collected. This action includes associating the brand with the sector throughout the world and with customer needs. Brazil IT + achieves this goal using the aspects associated with the brand and through the brand's elements and applications.

Keller (1993) suggests that the brand should be linked to the mind of customers by tangible and intangible brand associations with certain properties. In this sense, with its name, logo, slogan, colors and applications, Brasil IT+ displays the values that it intends to convey to the mind of its target audience. In addition, Kotler and Keller (2009) indicate that brand elements should be selected carefully and in such a way to create brand equity. The Brasil IT+ Guide demonstrates that the name was selected and developed to reflect neutrality and the sector's unity and makes the brand's objectives clear.

Regarding the creation of a specific name, Murphy (1987) suggests that the name be meaningful in other countries. During the creation of the name Brasil IT + , there was a concern to find a name that was globally meaningful and that conveyed the brand's values. Consequently, "Brazil" was written with an "s" to reflect Brazilian authenticity.

As a sector brand, it is obvious that the brand is subject to use by more than one enterprise and by different types of enterprise. The only criteria would be that all of the enterprises belong to the Brazilian Information Technology sector. According to Kotler and Keller (2009), an umbrella brand covers many individual brands, or sub-brands. The brand studied in the present article should be considered an umbrella brand because the brand represents all of the individual brands of the entities that are involved in the project of developing Brasil IT+, thus creating a seal of approval for the sector's enterprises to use in their marketing efforts.

Finally, Aaker (1996) offers the idea that it is necessary for the product represented by the brand to truly offer quality and benefit to consumers in harmony with the image that the brand attempts to convey. In this sense, the interviewee was asked if there was a way to exercise control over the enterprises that use the brand, and it was confirmed that no such control exists. However, there are indirect programs developed by private initiatives to improve the maturity and quality of the solutions and services provided for export. According to Kotler and Gertner (2004), there should be a control on exports to verify the performance of the enterprises involved.

\subsection{Competitive Advantages That the Creation of the Brasil IT+ Brand Can Generate}

In relation to the second specific objective ("to note sources of competitive advantage to the IT sector based on the use of the Brasil IT+ brand") and its respective question ("What competitive advantages can brand creation generate?"), the three propositions were confirmed. The creation of the brand generated competitive advantages, the brand provided a market identity for the sector and Brazilian origin influenced customer perception in relation to IT services and marketing.

To verify the creation of sector-specific competitive advantages as a result of the development of the brand, it was necessary to know, based on Aaker (1996), the motivation to create the sector brand and the objectives and strategies. In a complementary manner, Domeisen (2003) argues that the brand should able to emphasize differences and produce competitive advantages for the sector that the brand represents. In this sense, the Brasil IT+ brand attempted to create a competitive differentiator and show the global market that only Brazil possesses the business expertise, the creativity, the flexibility, the diversity, the infrastructure and the excellent conditions required to develop solid partnerships. In addition to displaying the national characteristics that are important to the sector, such as the capacity to understand problems, meet needs completely and surpass market expectations, the brand should establish the country as a global player. 
Regarding the creation of a differentiator, the meanings that the brand sought to convey were based on the four brand pillars: being Brazilian, transportation capabilities, building high-quality partnerships and being a strategic IT player. This definition agrees with that proposed by Keller (1993), who suggests the establishment of the meanings and images to be displayed. Kotler and Keller (2009) argue that the brand should suggest the sector. In this respect, Brasil IT+ attempts to evoke a technological country and associate that image with national characteristics such as originality and creativity.

In contrast, Brazil does not possess the image of a technology supplier, which can affect IT sector exports. The initial vision that one has of Brazil is of a natural resources exporter. This impression agrees with what Iversen and Hem (2008) and Roth, Diamantopoulos and Montesinos (2008) report regarding the influence of country of origin in the marketing of products and services.

\section{Final Considerations}

The present study proposed to understand and analyze how the Brasil IT + brand creation process occurred. The study concludes that the process of the creation of the Brasil IT + sector brand occurred in a suitable way based on the brand literature. This conclusion is valid, even though certain aspects of the process could have been improved according to suggestions presented below.

The first suggestion, which is based on Domeisen's theory (2003), would be for the brand to be adapted to each type of target audience. This adaptation could occur without requiring graphic alterations because the idea is to create an identity. Another suggestion, which follows Kotler and Gertner (2004), would be to establish some type of export control in terms of total exports to monitor the performance of enterprises after their participation in project activities that involve the brand. Additionally, according to the theory presented by Aaker (1996), it would be useful if there were some control over the quality of the enterprises that conduct business under the brand because the products must meet quality standards to boost the brand image.

In addition, it was possible to determine that the brand is investing in the construction of a competitive differentiator for the Brazilian sector, which will generate increasingly more competitive advantages for the enterprises that use the sector brand as a form of marketing in the international market.

For researchers, the present study represents a new source of information on the topic of country and, primarily, sector brands. Because this field is understudied, the present paper is a contribution to the understanding of the topic.

In addition, the analyses are relevant for the managers of the Brasil IT+ brand and consequently for the sector enterprises that conduct business under the brand. Each suitable application of the brand can help to develop the Brazilian IT sector on the global stage, thereby contributing to an increase in the country's export base and economic performance.

\subsection{Limitations and Recommendations for Future Studies}

Regarding the limitations of the study, a lack of literature can be noted, particularly with respect to the development of sector brands. This lack made the elaboration of case study protocol and the analysis of the collected information difficult. Another limitation resulted from this study's failure to analyze the customer perspective to verify the image's perception and the value of the Brasil IT+ brand and to investigate the opinion of the enterprises that already use the brand.

Therefore, future studies should include measuring the results of brand use by enterprises and the relevance of the brand in the marketing process. In addition, the level of repurchasing by prospective customers through events or other activities that involve the brand could be verified. A study that compares the level of sector exports before and after the beginning of brand-related activities is also needed.

\section{References}

Aaker D.A. (1996). Building strong brands. New York: Free Press.

Alonso A.D., \& Northcote J. (2009). Wine, history, landscape: origin branding in Western Australia. British Food Journal, 111(11), 1248-1259. http://dx.doi.org/10.1108/00070700911001068

Anholt S. (2000). The Nation as Brand. Across the Board, 37(10), 22-27.

Anholt S. (2007). Competitive Identity: The New Brand Management for Nations, Cities and Regions (1st ed.) Houndmills: Palgrave Macmillan.

Apex-Brasil. (2009). Guia Brasil IT+. Agência Brasileira de Promoção de Exportações e Investimentos. [S.1.]. 
Apex-Brasil. (2011). About Brasil IT+. Apex Brasi1. [Online] Available: http://www.apexbrasil.com.br/brasilit/en/sobre.html (29 May 2011)

Bivolaru E., Andrei R., \& Purcăroiu G.V. (2009). Branding Romania: a pestel framework based on a comparative analysis of two country brand indexes. Management \& Marketing, 9(4), 101-112.

Blue G. (2009). Branding Beef: Marketing, Food Safety, and the Governance of Risk. Canadian Journal of Communication, 34(2), 229-244.

Brasil. (2010). Ministério de Turismo. Logotipos e marcas: Marca Brasil. [Online] Available: http://www.turismo.gov.br/turismo/multimidia/logotipos_marcas/marca_brasil.html (21 May 2011)

Brymer C. (2005). Branding a country. [Online] Available: http://www.brandchannel.com/images/papers/Country_Branding.pdf (18 September 2011)

Dinnie K. (2008). Nation Branding: Concepts, Issues, Practice. Oxford: Butterworth-Heinemann.

Domeisen N. (2003). Is there a case for National Branding? International Trade Forum, (1), 14-16.

Federacafe. (2010). Federación Nacional de Cafeteros de Colombia. Juan Valdez. [Online] Available: http://www.juanvaldez.com (29 September 2011)

Fetscherin M. (2010). The determinants and measurement of a country brand: the country brand strength index. International Marketing Review, 27(4), 466-479. http://dx.doi.org/10.1108/02651331011058617

Giraldi J.M.E, \& CarvalhoD.T. (2009). A Imagem do Brasil no Exterior e sua Influência nas Intenções de Compra. RAC-Eletrônica, 3(1), 22-40.

Han C.M. (1990). Testing the Role of Country Image in Consumer Choice Behaviour. European Journal of Marketing, 24(6), 24-40. http://dx.doi.org/10.1108/EUM0000000000609

He H.W, \& Balmer J.M.T. (2006) Alliance brands: Building corporate brands through strategic alliances? Journal of Brand Management, 13(4/5), 242-256. http://dx.doi.org/10.1057/palgrave.bm.2540268

Iversen, N.M., \& Hem L.E. (2008). Provenance associations as core values of place umbrella brands. A framework of characteristics. European Journal of Marketing, 42(5/6), 603-626. http://dx.doi.org/10.1108/03090560810862534

Jack E.P., \& Raturi A.S. (2006). Lessons learned from methodological triangulation in management research. Management Research News, 29(6), 345-357. http://dx.doi.org/10.1108/01409170610683833

Jaffe E.D., \& Nebenzahl I.D. (2001). National Image \& Competitive Advantage: The theory and practice of Country-of-origin effect $\left(1^{\text {st }}\right.$ ed.). Copenhagen: Copenhagen Bussiness School Press.

Keller K.L. (1993). Conceptualizing, measuring and managing customer-based brand equity. Journal of Marketing, $57(1), 1-22$.

Kotler P., \& Gertner D. (2002). Country as brand, product, and beyond: A place marketing and brand management perspective. Journal of Brand Management, 9(4/5), 249-261. http://dx.doi.org/10.1057/palgrave.bm.2540076

Kotler P., \& Gertner D. (2004). O estratégico marketing de lugares. Dossiê HSM Management, 44.

Kotler P., \& Keller K.L. (2009). Marketing management (13 ${ }^{\text {th }}$ ed.). Upper Saddle River, N.J.: Pearson Prentice Hall.

Magnusson P., Westjohn S.A., \& Zdravkovic S. (2011). "What? I thought Samsung was Japanese": accurate or not, perceived country of origin matters. International Marketing Review, 28(5), 454-472. http://dx.doi.org/10.1108/02651331111167589

Murphy J.M. (1987). Branding: a key marketing tool. Nova York, McGraw-Hill.

Pavoni Junior G. (2010). O que a TI nacional ganha com a marca Brasil IT+. CRN Brasil. [Online] Available: http://crn.com.br/22351/o-que-a-ti-nacional-ganha-com-a-marca-brasil-it/ (14 May 2011)

Rajagopal, Sanchez R. (2004). Conceptual analysis of brand architecture and relationships within product categories. Journal of Brand Management, 11(3), 233-247. http://dx.doi.org/10.1057/palgrave.bm.2540169

Rocha A., \& Mello R.C. (2011). Como e Quando Usar o Selo Made in Brazil. Biblioteca Sebrae. [Online] Available: http://www.biblioteca.sebrae.com.br/bds/bds.nsf/1d7b269b07fee04a03256eae005ec615/e34628446267cbb08325784 60082f12a/\$FILE/NT00045402.pdf (16 May 2011)

Roth K.P.Z., Diamantopoulos A., \& Montesinos M.A. (2008). Home Country Image, Country Brand Equity and Consumers' Product Preferences: An Empirical Study. Management International Review, 48(5), 577-602. 
http://dx.doi.org/10.1007/s11575-008-0031-y

Shimp T.A., \& Sharma S. (1987). Consumer Ethnocentrism: Construction and Validation of the CETSCALE. Journal of Marketing Research, 24(3), 289-289.

Yan J. (2008). Ethical imperatives in nation branding: smaller nations enter the global dialogue through nation branding. In Dinnie, K. (Ed.), Nation Branding: Concepts, Issues, Practice (170-179). Oxford: Butterworth Heinemann.

Yin R.K. (2009). Case Study Research: Design and Methods (3rd ed.). Los Angeles, Calif.: Sage Publications.

Table 1. Stages in the development of country brands

\section{Confirm readiness}

Will adopting a strategy that includes a national brand bring competitive advantages? In other words, will the brand increase the country's export base? What national values are relevant for the export of products and services?

\section{Creation of a working group}

This group includes politicians, civil servants, industry representatives, the media, educators and figures from sports and art. Determine whom you are trying to influence and confirm how this target audience perceives the nation. Begin by identifying and defining your key internal and external audiences.

\section{Identification of a main idea}

Identify both internal and external country images and perceptions, including positive, negative, and neutral ones, as well as their absence. Identify the differences between these images internally and externally. Discover the difference, and subsequently create something in relation to the difference. Sunshine and sandy beaches are not main ideas; they represent commodities.

\section{Coordinating the presentation of the main idea}

Guarantee that the key public and private entities that are involved in tourism, investment and export development transmit the main message in their programs.

\section{Differentiate the messages}

Once the idea is developed, it must be modulated for each priority. Create a visual idea that can be expressed in words.

\section{Manage the messages}

Do not allow government to be the executor of the process. Create a structure that will remain, despite changes in government. Guarantee that the brand is being promoted for the local public and guarantee the brand's credibility through the development of standards for its use.

\section{Establish a long-term structure}

Country branding is a long-term initiative. A 20 -year term is realistic.

Source: Prepared by authors, based on Domeisen (2003). 
Table 2. Study questions and propositions

\begin{tabular}{|c|c|c|c|}
\hline Specific objectives & $\begin{array}{c}\text { Study } \\
\text { questions }\end{array}$ & Propositions & Bibliographic Sources \\
\hline \multirow{2}{*}{$\begin{array}{l}\text { To compare the } \\
\text { Brasil IT+ brand } \\
\text { development } \\
\text { process with the } \\
\text { process as } \\
\text { described in the } \\
\text { brand literature. }\end{array}$} & \multirow{2}{*}{$\begin{array}{l}\text { Did the brand } \\
\text { creation process } \\
\text { follow the path } \\
\text { indicated in the } \\
\text { literature? } \\
\text { What were the } \\
\text { difficulties } \\
\text { associated with } \\
\text { this process } \\
\text { which may have } \\
\text { interfered with } \\
\text { the positive } \\
\text { assessment of } \\
\text { brand } \\
\text { development? }\end{array}$} & $\begin{array}{l}\text { The process followed established } \\
\text { models outlined in the literature. } \\
\text { There is a structure parallel to the } \\
\text { government that addresses brand } \\
\text { management. }\end{array}$ & \multirow[b]{2}{*}{$\begin{array}{c}\text { Domeisen (2003); Kotler and } \\
\text { Gertner (2004); Murphy (1987); } \\
\text { Keller (1993); Kotler and Keller } \\
\text { (2009); Aaker (1996); Kotler and } \\
\text { Gertner (2004). }\end{array}$} \\
\hline & & $\begin{array}{l}\text { Actions were developed to associate } \\
\text { the brand with the IT sector. }\end{array}$ & \\
\hline \multirow{4}{*}{$\begin{array}{l}\text { To note sources of } \\
\text { competitive } \\
\text { advantage to the IT } \\
\text { sector based on the } \\
\text { use of the Brasil } \\
\text { IT + brand. }\end{array}$} & \multirow{4}{*}{$\begin{array}{l}\text { What } \\
\text { competitive } \\
\text { advantages can } \\
\text { brand creation } \\
\text { bring? }\end{array}$} & $\begin{array}{l}\text { The creation of the brand led to } \\
\text { competitive advantages. }\end{array}$ & $\begin{array}{c}\text { Apex-Brasil; Aaker } \\
\text { (1996); Domeisen (2003); }\end{array}$ \\
\hline & & \multirow{2}{*}{$\begin{array}{l}\text { The brand provides an identity for the } \\
\text { sector in the market; in other words, } \\
\text { the brand differentiates Brazilian IT } \\
\text { from other countries' IT sectors. }\end{array}$} & $\begin{array}{l}\text { Keller (1993); Kotler and Keller } \\
\text { (2009); }\end{array}$ \\
\hline & & & \multirow{2}{*}{$\begin{array}{l}\text { Iversen and Hem (2008); Roth, } \\
\text { Diamantopoulos and Montesinos } \\
\text { (2008); Kotler and Gertner (2004); } \\
\text { Anholt (2007); Rocha and Mello } \\
\text { (2011); Han (1990). }\end{array}$} \\
\hline & & $\begin{array}{l}\text { Brazilian origin influences customer } \\
\text { perception in relation to the provision } \\
\text { of IT products and services. }\end{array}$ & \\
\hline
\end{tabular}

Source: Prepared by the authors. 